\title{
Application of the AHP Method to Select an Optimal Source of Financing Innovation in the Mining Sector
}

\author{
Ryszard Pukala ${ }^{1}$, and Mariana Petrova ${ }^{2, *}$ \\ ${ }^{1}$ Bronislaw Markiewicz State Higher School of Technology and Economics in Jaroslaw, \\ Czarnieckiego St., 16, 37-500 Jaroslaw, Poland \\ ${ }^{2}$ St. Cyril and St. Methodius University of Veliko Tarnovo, Veliko Tarnovo, Bulgaria
}

\begin{abstract}
This study intends to present a possibility of applying the AHP method in the process of making managerial decisions concerning the selection of sources of financing innovation by mining enterprises. Such companies, active in a turbulent market environment marked by increasing competition, are looking for new tools and solutions with a view to supporting and optimising their activity. Development and implementation of innovations, principally aimed at improving the effectiveness of enterprise operation and lowering operating costs, is an efficient tool for the sake of gaining competitive advantage. As shown by studies, the presented method can make an appropriate instrument when it comes to selecting sources of financing for an enterprise. The conducted analyses demonstrated that offtake agreements can be an optimal method of financing innovation in mining companies, in line with indications of experts participating in the study.
\end{abstract}

\section{Innovation in the mining sector}

Contemporary economy is characterized by high dynamics of changes and a quest for new solutions that yield tangible benefits and allow activating innovative business operations by enterprises. Their activity, based on new and often unique technologies, contributes to safeguarding durable and sustainable growth.

Innovation is a very popular, albeit imprecisely understood term. Most commonly innovation is associated with modern technologies, although they only represent a fragment of the innovation process. When analysing the term innovation, we definitely need to refer to the work of the precursor of studies on this phenomenon - J.A. Schumpeter - who defined it as [1]:

- introduction of a new product;

- introduction of a new production method (process innovation);

- opening of a new sales market;

\footnotetext{
* Corresponding author: m.petrova@ts.uni-vt.bg
} 
- opening of a new supply market;

- introduction of a new form of organization.

The five abovementioned types of innovation indicate that it was (and continues to be) associated with introducing something new to the operation of a given enterprise. This path was followed by other researchers as well, among whom, for example, J.A. Allen declared that innovation could be defined as an introduction of new products, processes or a manner of conduct to wide usage [2], while P.R. Whitfield indicated that innovation could be defined as every modification based on the assimilation of transferred knowledge [3]. The definition of innovation coined by E.M. Rogers is also a very broad concept [4]. He stated that innovation was the introduction of new products, processes or a manner of conduct to popular use. H.G. Barnett defined innovation differently, as he based his definition on an assumption that it is every concept, idea, attitude, position or thing that stands out against all previous ones in terms of quality [5]. Innovation is also explained as a process of creative use of knowledge, transformation of knowledge, either in possession by an organization or acquired from outside, into new products, services or processes [6]. It is worth correlating the term innovation with an enterprise activity here. As indicated by S. Shane, entrepreneurship encapsulates activities that include identification, assessment and making use of chances of introducing new products and services, methods of organisation, markets, processes and raw materials by a given entity, plus efforts made in a previously unseen way, which can be directly inscribed into a definition of innovation [7].

Scientists dealing with innovation in a global sense have developed a standard definition, which has been published by the EC under the title "The Oslo Manual" [8]. It represents a point of reference for the majority of studies on innovation. According to a definition contained therein, innovation is "the implementation of a new or significantly improved product (good or service), or process, a new marketing method, or a new organizational method in business practices, workplace organization or external relations". Therefore, it is important to perceive innovation two-dimensionally. The first dimension is to define what it actually is: a new product (service), a new process, a new marketing type or a new organisational method. The other dimension is to make an assumption that innovation represents a certain novelty for an enterprise. It does not have to be a breakthrough technology or global-scale innovation. It shall be sufficient that a company introduces products, services, processes, sales methods and organisational methods that are significantly different from the previously applied ones.

A lot of businesses are looking for innovative ways to improve efficiency and maintain competitive advantage in order to survive $[9,10]$. Innovation is present in all sectors of the economy, obviously including mining, where modern solutions are supposed to support, among others, the extraction process and safety of persons working in very hard conditions. This requires the development of various techniques for improving their business competitiveness [11-15]. The most important areas of innovation include robotics, telecommunications, micro-seismic monitoring, use of drones, satellite technologies or virtual reality.

Owing to the implementation of innovations, especially information technologies and automation of the extraction processes, enterprises can focus to a greater extent on the elimination of hazards and reduction of risks generated by the extractive industry. Today, the sector aims at creating unmanned mines, where the role of employees will be limited to supervising machines that deal with coal extraction. However, we need to underline that without building an innovative organisational structure in mining companies, without the business dimension, acceptance of mistakes made and, most of all, without funds for the development and implementation, innovation will fail to deliver satisfactory results. 


\section{Selection of an optimal method of financing innovation}

An optimal method of financing innovation in mining companies has been selected by means of the Analytic Hierarchy Process (AHP). One of the main tasks of this method is to make a quantitative assessment of intangible phenomena where unambiguous functional relationships between the components of the analysed problem are unknown, but where the problem can be described by a hierarchical structure of the criteria. This is one of the world's best-known mathematical methods applied to solving multi-criteria decisional problems. Its advantages include easy application, universality, high degree of flexibility and high efficiency. The AHP method combines subjective expert methods with an unbiased, mathematical analysis of results obtained through surveys, concerning hierarchical partial interrelations and dependencies between them. The method's underlying claim provides that human opinions are relative and depend on the person's character, current role and a system of values. This method takes account of the specificity of psychological value attribution processes that are mainly relational and hierarchical $[16$, 17].

In order to quantify assessments, decisional variants and criteria are compared in pairs by means of a ten-grade scale (the Saaty scale), which can be applied both to analyses of quantitative and qualitative variables. It is characterized by numerous stages, which allows creating rankings of decision-making variants examined [18]. The scale proposed by $\mathrm{T}$. Saaty allows making use of experience and knowledge of persons who make decisions and indicating how many times a given element prevails over others, e.g. with regard to a given criterion [19].

A study dedicated to determining an optimal source of financing innovation in mining companies was carried out among 10 experts, including analysts and practitioners related to the industry of our interest based in Poland. Opinions formulated by a relatively small number of experts who participated in the study do not enable us to articulate conclusions that could be representative for the entire sector. They do, however, form a basis for indicating inclinations of decisional behaviour as regards a selected group of mining enterprises and for expressing conclusions that could help in the process of making decisions by competent individuals involved in the process of managing those enterprises.

In the course of the study pilot interviews were conducted, as part of which the experts expressed their opinions on the most popular traditional and alternative sources of financing innovation. They included a banking credit, a supplier credit, financial leasing, monetisation of production (offtake agreements), standby equity and finance development. Moreover, 5 most important categories of assessing such sources from the point of view of usefulness for an enterprise were defined. They included cost, availability, waiting time for funds, limitations in the use of funds and funds volume. Then the experts were asked to fill in the questionnaire of decisional pairs on the basis of the 9-grade Saaty scale. The analysis of collected questionnaires consisted of three main stages: setting individual priorities of the hierarchical structure through the Super Decisions software, aggregation of results with regard to priorities and assessment of preference of alternatives by means of an arithmetic average.

The obtained data are presented in Table 1.

The resulting hierarchical structure index $\mathrm{CR}=0,1$, which indicates that results can be deemed reliable.

As seen from the conducted study, an optimal source of financing innovation in mining enterprises is monetisation of production in the form of offtake agreements. 
Table 1. Selection of an optimal innovation in the mining sector financing method

\begin{tabular}{|c|c|c|c|c|c|c|}
\hline Parameter & Cost & Availability & $\begin{array}{c}\text { Waiting } \\
\text { time }\end{array}$ & $\begin{array}{c}\text { Restrictions } \\
\text { of use }\end{array}$ & $\begin{array}{c}\text { Volume } \\
\text { of funds }\end{array}$ & Ratio \\
\hline $\begin{array}{c}\text { Banking } \\
\text { credit }\end{array}$ & 0.0245 & 0.0309 & 0.0098 & 0.0304 & 0.0376 & 0.1332 \\
\hline $\begin{array}{c}\text { Supplier } \\
\text { credit }\end{array}$ & 0.0363 & 0.0204 & 0.0087 & 0.0381 & 0.0274 & 0.1310 \\
\hline $\begin{array}{c}\text { Financial } \\
\text { leasing }\end{array}$ & 0.0659 & 0.0452 & 0.0158 & 0.0152 & 0.0544 & 0.1965 \\
\hline $\begin{array}{c}\text { Standby } \\
\text { equity }\end{array}$ & 0.0281 & 0.0142 & 0.0052 & 0.0242 & 0.0223 & 0.0940 \\
\hline $\begin{array}{c}\text { Finance } \\
\text { development }\end{array}$ & 0.0338 & 0.0189 & 0.0063 & 0.0142 & 0.0196 & 0.0928 \\
\hline $\begin{array}{c}\text { Monetisation } \\
\text { of production }\end{array}$ & 0.1038 & 0.0778 & 0.0250 & 0.0679 & 0.0780 & 0.3526 \\
\hline
\end{tabular}

Source: own calculations supported by Super Decisions software.

\section{Offtake contracts as a source of financing innovation}

Offtake agreements refer to alternative sources of financing innovation, where the essence lies in concluding an agreement by a client and a manufacturer for the receipt of a product by the former. Such an agreement can include the obligation to make an advance payment to the manufacturer and can refer to a delivery of a certain product volume to the recipient. This way, through guaranteeing sale and obtaining revenue in effect, it can constitute an enterprise development source and a collateral for granting traditional financing in the form of third party equity from banks or other financial institutions.

The offtake agreement provides tangible benefits for the manufacturer when it comes to steady operation within a strategic time horizon. When concluding the agreement, the buyer relies on the future production of a raw material. Usually the purchased product does not exist yet, so the agreement is usually collateralised by future assets to be delivered.

Offtake agreements usually deal with longer time horizons - between 10 and 25 years, depending on the type of project and generated cash flows that will allow debt servicing and covering ongoing investment overlays and operating costs [20].

Depending on the collateral for the repayment of external funding as part of offtake agreements, the following types can be identified:

1. Take-It-Offered, as part of which the buyer obliges to accept the delivery of a product and make a payment to the mining enterprise [21]. This option enables the mining enterprise to sell its produce and if the delivery is not possible, it does not bear any financial consequences.

2. Take-Or-Pay, which obliges the buyer to pay, regardless of whether the produce has been delivered or not [22].

3. Hell-or-High-Water Contract, similar to the Take-Or-Pay contract, with a significant difference in the form of an exclusion of any justifications made by the buyer intended to dodge the payment [21].

4. Prepayment Contract, as part of which the parties thereto take note that the buyer makes a down payment for the delivered product.

5. The tripartite Offtake Agreement, as part of which the buyer directly pays the cash for the received product to the borrower or the latter is authorized to use the banking accounts of the manufacturer, from where they can satisfy their claims.

Alternative funding in the form of offtake agreements is significant in industries where traditional sources of capital are hard to acquire. Such industries include mining, which has been undergoing a thorough restructuring of its operational, investment and financial 
processes in recent years, followed by seeking new instruments to support its activity, aimed at increasing efficiency and safety of extraction.

\section{Summary}

The globalisation process favours the expansion of international economic relations and cooperation. Joint technical undertakings and scientific research also develop. This all requires familiarity with regularities, mechanisms and innovation and development tendencies that take place, revision of assessment criteria, operating principles of stimulators as well as an identification of barriers for innovation.

The contemporary mining industry is undergoing numerous changes resulting from an ever broader application of innovations aimed at supporting the activity of enterprises operating within its structures. These innovative activities aim at gaining competitive advantage in a turbulent market environment and entering new sales markets.

Through such activities these enterprises implement solutions that support development. They also make use of a broader spectrum of innovation financing tools that are available on the market and that are customised to reflect the needs of each enterprise.

As shown by the results of the conducted study, the application of offtake agreement by mining enterprises can become such an instrument, as these agreements allow an efficient use of external sources of funding, in this case recipients of produce, in order to carry out activities in the field of modernising the enterprise through, among others, implementing various types of innovations.

It is worth emphasizing that to select an optimal source of financing innovation, an enterprise can apply the AHP method in its decision-making process, which enables them to determine a preferred financial instrument and is relatively easy to use. It is to be hoped that the presented method will be used to a broader extent by mining enterprises as a tool for supporting their activity in the area of making various types of managerial decisions.

\section{References}

1. J.A. Schumpeter, Teoria rozwoju gospodarczego (PWN, Warszawa 1960)

2. J.A. Allen, Scientific innovation and industrial prosperity (Longman, London 1966)

3. P.R. Whitfield, Innowacje w przemyśle (PWE, Warszawa, 1979)

4. E.M. Rogers, Diffusion of innowations (Free Press, New York, 2003)

5. P.F. Borowski, Europejski Doradca Samorządowy, 17:2, 90 (2011)

6. D. Cavagnoli, Innovation: Management, Policy and Practice, 13, 4 (2011)

7. S. Shane, A General Theory of Entrepreneurship. the Individual - Opportunity Nexus (Edward Elgar Pub., Northampton, 2003)

8. Oslo Manual, Podręcznik Oslo. Zasady gromadzenia $i$ interpretacji danych dotyczacych innowacji (Komisja Europejska, Warszawa, 2008)

9. M. Petrova, M. Tepavicharova, L.Boykova, E3S Web Conf., 41, 04017 (2018)

10. Y. Dyachenko, N. Nenkov, M. Petrova, I. Skarga-Bandurova, O. Soloviov, Biologically Inspired Cognitive Architectures, 26, 130-135 (2018)

11. Sv. Labunska, M. Petrova, O. Prokopishyna, Economic Annals - XXI, 165:5-6, 3-18 (2017)

12. O. Sushchenko, I. Trunina, Actual Problems of Economics, 177:3, 191-198 (2016) 
13. A.B. Bogomolov, V.P. Nevezhin, L.O. Chagovets, IEEE First International Conference on System Analysis \& Intelligent Computing (SAIC), 1, 1-5 (2018)

14. T. Uteubayev, CBU, 3, 150 (2015) DOI: http://dx.doi.org/10.12955/cbup.v3.596.

15. T. Odinokova, M. Bozhinova, M. Petrova, E3S Web Conf., 41, 04015 (2018)

16. I. Trunina, O. Sushchenko, Modern Electrical and Energy Systems (MEES, Kremenchuk, 2017)

17. O. Downarowicz, J. Krause, M. Sikorski, W. Stachowski, Zastosowanie metody AHP do oceny $i$ sterowania poziomem bezpieczeństwa złożonego obiektu technicznego (Wydawnictwo Politechniki Gdańskiej, Gdańsk, 2000)

18. R. Pukala, N. Vnukova, S. Achkasova, Konsument na rynku usług finansowych, 23, 1 (2017)

19. T. Saaty, European Journal of Operational Research, 48, 27 (1990)

20. W. Adamus, P. Łasak, Bank i Kredyt, 4, 50 (2010)

21. A. Kustra, R. Ranosz, Przegląd Górniczy, 8, 32 (2015)

22. J.D. Finnerty, Asset-Based Financial Engineering (John Wiley \& Sons, New Jersey, 2007)

23. Offtake Agreements: Role Features And Alternatives For Project Finance, URL: http://www.dundee.ac.uk/cepmlp/gateway/ 